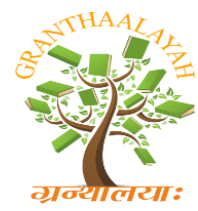

INTERNATIONAL JOURNAL OF RESEARCH GRANTHAALAYAH

A knowledge Repository

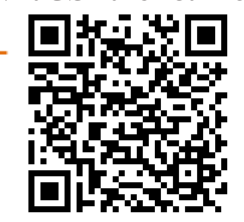

Management

\title{
A STUDY ON STRESS MANAGEMENT OF SECURITY GUARDS WITH SPECIAL REFERENCE TO TRIVANDRUM DISTRICT
}

\author{
Suginraj $M^{* 1}$ \\ ${ }^{* 1}$ Asst Professor, Dept of Commerce, Malankara Catholic College-Mariagiri, INDIA
}

\begin{abstract}
Stress refers to the strain from the conflict between our external environment and us, leading to emotional and physical pressure. In our fast paced world, it is impossible to live without stress. This study analyzed the stress level of security guards who are working in public and private sectors as employees. Randomly selected 100 samples from Trivandrum district and conducted descriptive cum diagnostic research to analyze the causes and outcomes of stress. This study has been found that $80 \%$ of security guards suffer from depression at their work place, 55\% of security guards feels that they do not have time to enjoy their personal life, back pain and head ache are the major symptoms of stress, financial motivation is being a more preferred method to control the stress and subsequently changes in work load and spending time with family are to be best methods to control the stress among the security guards.
\end{abstract}

Keywords:

Stress, security guards, causes and outcomes of stress.

Cite This Article: Suginraj M, "A STUDY ON STRESS MANAGEMENT OF SECURITY GUARDS WITH SPECIAL REFERENCE TO TRIVANDRUM DISTRICT" International Journal of Research - Granthaalayah, Vol. 4, No. 5: SE (2016): 12-17.

\section{INTRODUCTION}

Stress in individual is defined as any interference that disturbs a person's healthy mental and physical well-being. It occurs when the body is required to perform beyond its normal range of capabilities. Stress is the way that people react physically, mentally and emotionally to various conditions, changes and demands in personal life. The results of the stress are harmful to individuals, families, society and organizations. This study is analyzed the employees who are working in public and private sector as security guards. This paper is an attempt to identify the level of stress and the techniques to reduce the stress among the security guards. This study will help to do further research in this area and helps to fulfill the expectation of the security guards.

\section{OBJECTIVES OF THE STUDY}

- To ascertain the causes of stress - sources of stress 
- To identify the individual and organizational strategies and tools to cope with stress

- To find out some of the outcomes of stress like physical and physiological problems of security guards.

\section{METHODOLOGY}

\section{NATURE OF STUDY}

Descriptive research studies are those studies which are concerned with describing the characteristics of a particular individual or of a group, whereas diagnostic studies determine the frequency with which something occur or its association with something else. In this study the researcher has adopted descriptive cum diagnostic research design because the researcher described the various stressors and measure the level of stress that each employee undergoes in his job with selected socio - demographic variations.

\section{SAMPLING DESIGN}

The researcher has used random sampling to collect the data from the 100 respondents. The primary data collected through the structured questionnaire from the security guards who are working public and private sector organization such as banks, ATMs, company and hotels with in Trivandrum district.

\section{REVIEW OF LITERATURE}

1) P.Kannan and Suma (2015) in their study entitled "Managing Stress among Co-Operative Bank Employees in Palakkad district" examined the effect of stress on work factors (e.g., morale, job satisfaction, task effort,Organizational commitment, etc) and identified the meditation as a method and techniques to reduce the stress among bank employees.

2) Tilottama Azad (2014), the study entitled "Managing Stress among Banking Sector Employees in Bhopal" explored the stress related problems of bankers and examined the relationship of stress and performance. The researcher found in this study that Work life imbalance is one of the major attribute which contribute to stress for an employee. Then stress creates certain impacts in organization like job dissatisfaction, behavioral problems, and production turn over, increased absenteeism, increased accidents, lower productivity.

3) Azizi Yahaya, Noordin Yahaya, Abdul Talib Bon, Sharifuddin Ismail and Tan Chui Ing (2011) the study entitled "Stress level and its influencing factors among employees in a plastic manufacturing and the implication towards work performance" study shows the important outcomes that approximately one in five workers reported stress arising from work. There were cause by excessive workloads or lack of managerial support, ill health and back pain, together with certain health related activities such as smoking and alcohol intake.

\section{ANALYSIS AND INTERPRETATION}

1) The causes of stress /stressors - sources of stress

\begin{tabular}{|l|l|l|l|l|l|}
\hline & S.Agree & Agree & Undecided & Disagree & S.Disagree \\
\hline
\end{tabular}




\begin{tabular}{|l|l|l|l|l|l|} 
Physical environment & 2 & 11 & 11 & 52 & 24 \\
\hline Time pressure & 6 & 18 & 24 & 28 & 24 \\
\hline $\begin{array}{l}\text { Higher authorities } \\
\text { pressure }\end{array}$ & 0 & 0 & 19 & 32 & 49 \\
\hline $\begin{array}{l}\text { Lack of } \\
\text { communication }\end{array}$ & 0 & 1 & 26 & 44 & 29 \\
\hline Delay in promotions & 63 & 25 & 7 & 5 & 0 \\
\hline No time to enjoy life & 29 & 26 & 28 & 17 & 0 \\
\hline Family problem & 8 & 22 & 30 & 38 & 2 \\
\hline
\end{tabular}

Source: Primary data

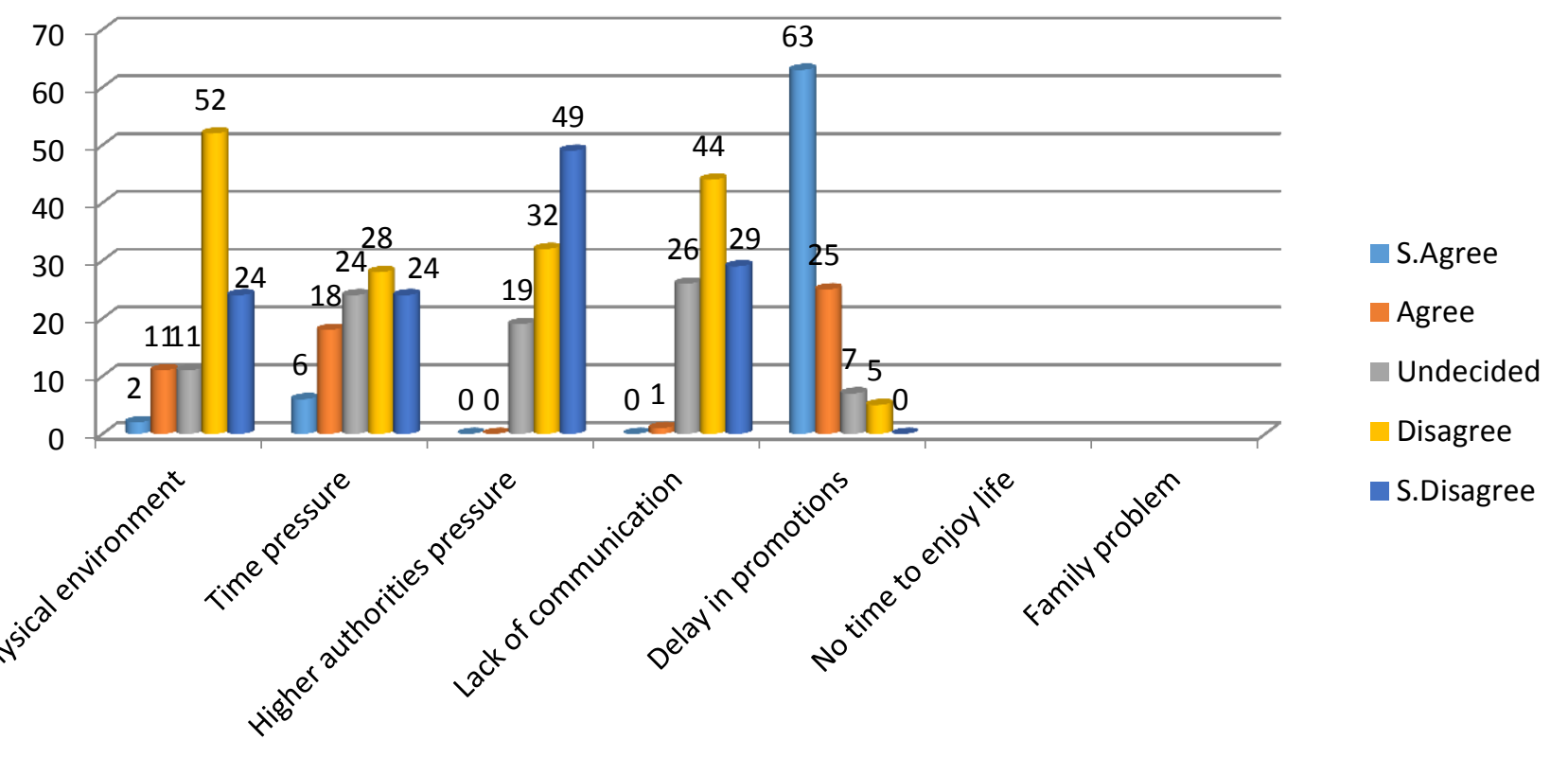

2) Outcomes of stress (physical and physiological problems of security guards)

\begin{tabular}{|l|l|l|}
\hline & YES & NO \\
\hline Tension head aches & 74 & 26 \\
\hline Over eating & 0 & 100 \\
\hline Back pain & 92 & 8 \\
\hline
\end{tabular}




\begin{tabular}{|l|l|l|} 
Blood pressure & 18 & 82 \\
\hline Irritability & 35 & 65 \\
\hline $\begin{array}{l}\text { Aching neck and shoulders } \\
\text { muscles }\end{array}$ & 53 & 47 \\
\hline Heart ailments & 19 & 81 \\
\hline Angry feeling & 14 & 86 \\
\hline
\end{tabular}

Source: Primary data

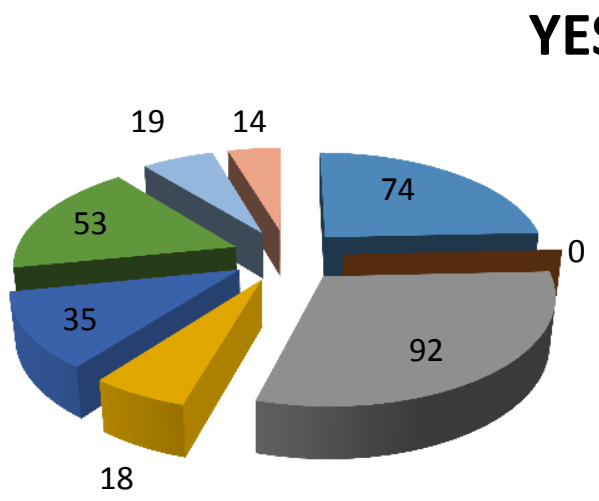

Tension head aches

Over eating

Back pain

Blood pressure

Irritability

Aching neck and shoulders muscles

3) Strategies and tools to cope with stress

\begin{tabular}{|l|l|l|l|l|l|}
\hline & S.Agree & Agree & Undecided & Disagree & S.Disagree \\
\hline $\begin{array}{l}\text { Improvement } \\
\text { in physical } \\
\text { work } \\
\text { environment }\end{array}$ & 2 & 11 & 11 & 52 & 24 \\
\hline $\begin{array}{l}\text { Changes in } \\
\text { work load }\end{array}$ & 53 & 41 & 0 & 6 & 0 \\
\hline $\begin{array}{l}\text { Flexible } \\
\text { working } \\
\text { hours }\end{array}$ & 24 & 10 & 51 & 10 & 5 \\
\hline $\begin{array}{l}\text { Strong work } \\
\text { life balance }\end{array}$ & 18 & 11 & 43 & 16 & 12 \\
\hline $\begin{array}{l}\text { Meditation } \\
\text { and prayers }\end{array}$ & 16 & 13 & 29 & 24 & 18 \\
\hline $\begin{array}{l}\text { Training and } \\
\text { development }\end{array}$ & 18 & 21 & 31 & 18 & 12 \\
\hline $\begin{array}{l}\text { Financial } \\
\text { motivation }\end{array}$ & 72 & 28 & 0 & 0 & 0 \\
\hline Spending & 42 & 31 & 20 & 7 & 0 \\
\hline
\end{tabular}




\begin{tabular}{|l|l|l|l|l|l|}
\hline $\begin{array}{l}\text { time with } \\
\text { family } \\
\text { members }\end{array}$ & & & & & \\
\hline $\begin{array}{l}\text { Family } \\
\text { counseling }\end{array}$ & 61 & 30 & 9 & 0 & 0 \\
\hline
\end{tabular}

Source: Primary data

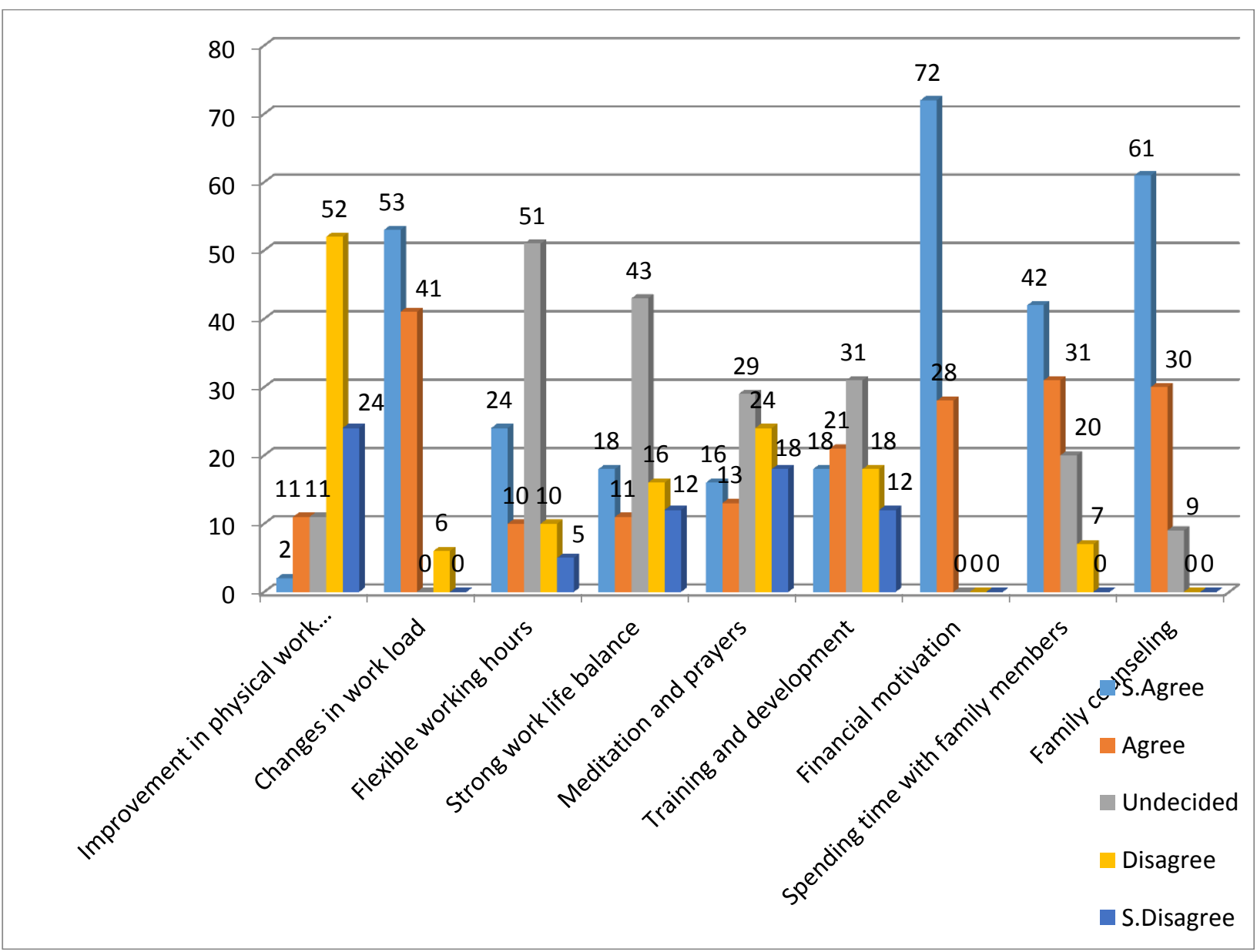

\section{FINDINGS}

1) $80 \%$ of respondents suffer from depression at their work place

2) $63 \%$ of respondents feel that they have delay in their promotions

3) $55 \%$ of respondents say that they do not have enough time to enjoy their family life

4) Family problems, lack of communication, higher authorities' pressure, time pressure to complete the job and physical work environment are not the major source of stress among security guards.

5) $74 \%$ of the respondents suffer from tension headaches, $92 \%$ of employees suffer from back pain. So these two symptoms are major outcomes of stress. Other outcomes of stress are neck and shoulder pain, heart ailments and angry feelings. 
6) Strong work life balance strategy, spending time with family, family counseling and financial motivations are best strategy to control the stress among security guards. Other tools like improvement in physical environment, flexible working times, meditation, training and development and relaxation are very less useful strategies to overcome the stress.

\section{SUGGESTIONS}

1) Avoid recruiting through the private agencies, because they are cheating uneducated security guards and collecting commission from their salary.

2) Security guards association may conduct workshops, training and development programs to the employees to overcome the stress

3) Employers should consider all security guards as human beings not as slaves of them and should respect their values.

4) Employers consider and provide all facilities to balance the work life

5) 8 hours work duty to be assigned to all security guards according the legal acts. Employers can allocate the duty on shift basis to security guards.

\section{REFERENCES}

[1] P.Kannan, Suma.U(2015) "Managing Stress among Co-Operative Bank Employees in Palakkad district" the International Journal of Scientific Engineering and Applied Science (IJSEAS) - Volume-1, Issue-7

[2] Tilottama Azad (2014) "Managing Stress among Banking Sector Employees in Bhopal" international journal of interdisciplinary research in social and management sciencesvolume -2 issue -2

[3] Azizi Yahaya, Noordin Yahaya, Abdul Talib Bon, Sharifuddin Ismail and Tan Chui Ing (2011) "Stress level and its influencing factors among employees in a plastic manufacturing and the implication towards work performance" international journal of Elixir psychology 41. 